This item was submitted to Loughborough's Research Repository by the author.

Items in Figshare are protected by copyright, with all rights reserved, unless otherwise indicated.

\title{
Anti-Muslim racism and the racialisation of sexual violence: 'intersectional stereotyping' in mass media representations of male Muslim migrants in Germany
}

\section{PLEASE CITE THE PUBLISHED VERSION}

https://doi.org/10.1080/14755610.2019.1658609

\section{PUBLISHER}

Taylor and Francis

\section{VERSION}

AM (Accepted Manuscript)

\section{PUBLISHER STATEMENT}

This is an Accepted Manuscript of an article published by Taylor \& Francis in Culture and Religion on 02 Sep 2019, available online: https://doi.org/10.1080/14755610.2019.1658609.

\section{LICENCE}

CC BY-NC-ND 4.0

\section{REPOSITORY RECORD}

Wigger, Iris. 2019. "Anti-muslim Racism and the Racialisation of Sexual Violence: 'intersectional Stereotyping' in Mass Media Representations of Male Muslim Migrants in Germany”. figshare.

https://hdl.handle.net/2134/9977255.v1. 


\title{
Iris Wigger
}

School of Social Sciences, Loughborough University, Loughborough, United Kingdom

\section{Anti-Muslim Racism and The Racialisation Of Sexual Violence: 'Intersectional Stereotyping' in Mass Media Representations of Male Muslim Migrants in Germany}

\begin{abstract}
This article examines how German print media have represented male migrants with Muslim backgrounds in relation to mainstream society and the stereotypes drawn on and created, including that of the migrant Muslim man as a criminal and sexual perpetrator. Media reports about 'lecherous refugees' have risen in the wake of wider social controversies about the European refugee crisis and the consequences of welcoming over 1.5 million refugees from predominantly Muslim countries into Germany in recent years. Many of these reports reflect the Cologne New Year's Eve 2016 sexual attacks by migrant men against German women. This study of German print media identifies a racialisation and 'islamicisation' of sexual violence and proposes the original theoretical concept of intersectional stereotyping to conceptualise the intersecting of religious, racialised and gendered patterns in media representations of male Muslim migrants. The research combines and extends the analytical frameworks of intersectionality and stereotyping to develop a new concept useful in media studies and beyond. The article provides a previously unexplored insight into racialised anti-Muslim stereotyping in German society in socio-political and historical context through the lens of print media.
\end{abstract}

Keywords: anti-Muslim racism in media; intersectional stereotyping;

Islamophobia; sexual violence; racialisation of sexism

Correspondence details

Dr Iris Wigger, School of Social Sciences, Loughborough University, Epinal Way,

LE113TU, email I.Wigger@lboro.ac.uk 


\section{Introduction}

Following the large-scale migration of refugees from Muslim majority countries to Europe between 2014-2016, social controversies about a so called 'European refugee crisis' have intensified in German society and across Europe. Media reports of 'lecherous refugees threatening German women' have exacerbated public debate, and were frequent after the events in Germany on New Year's Eve 2016, when large groups of migrant men (mainly Muslim, originating from North Africa) robbed and in several cases sexually assaulted German women in the train station area of Cologne and in some other German cities (Weber 2016, 77, 81). In the follow-up to these attacks, Germany's print media were accused by a number of critical voices of spreading racist, sexist and anti-Muslim stereotypes particularly of migrant men, after representing them as a danger to society (Schneider 2016). Public controversy about the alleged sexual menace of male refugees predates the Cologne attacks. A broadcast of the German political TV magazine 'Panorama' in October 2015 (Panorama 8.10.2015) reported on (unfounded) rumours about 'lecherous refugees' and emphasised the role of rightpopulist organisations in spreading fear and prejudice against refugees and nonEuropean migrants in German society.

This article examines how the mainstream print media in Germany have represented and constructed notions of 'migrant Muslim men' and analyses their role in promoting and reinforcing stereotypical narratives of this group. The analysis identifies frequent attempts by these media to racialise sexual violence as a problem associated with Islam and uncovers intersections of religious, racist and sexist patterns in their representation of male Muslim migrants. This study proposes that the concept of 'intersectional stereotyping' enables us to capture media representations where depictions of male Muslim migrants are entangled in multiple narratives of difference 
that intersect and form a toxic racist conglomerate of ascribed 'Otherness'. This intersectional stereotyping combines the racialisation of sexism and sexual violence with a gendered and religiously charged racism, framing Muslim migrant men as sexually deviant and dangerous criminals/harassers and associating this deviance with their religious belonging. I also explore this intersectional stereotyping in historical context, discussing its links to hegemonic Orientalist and colonial framings of black men as 'sex beasts' in Western society (Author, 2017) and reflect on ambivalences and discrepancies within the media reporting.

In what follows, I firstly map the socio-political context of German media discourses and public debates about immigration. I then review the academic discussion of the Cologne events and key literature on the Othering of migrants, media stereotyping and Islamophobia in relation to migration. I also outline the theoretical framework of this research and introduce the concept of 'intersectional stereotyping' as an analytical lens on media representations and anti-Muslim racism before describing the study's method. The third section presents findings from a qualitative thematic analysis of thirty-two articles in three German newspapers and a political weekly. It focuses on three main themes in the print media's reporting of male Muslim migrants: (1) intersections of gender, sexual violence and religion, (2) perceptions of male Muslim migrants as threatening 'Others' and (3) their association with crime.

My research engages with key sociological theories of media stereotyping, racialised Othering, anti-Muslim racism and Islamophobia. It draws on and combines the theoretical concepts of media stereotyping (Hall) and intersectionality (Crenshaw), which leads to the development of a new theoretical concept of 'intersectional stereotyping' focusing on the discursive deployment of multiple forms of stereotyping in media discourse. 


\section{The Cologne New Year's Eve events 2016 in the German socio-political context}

German newspaper reports about migration and the 'refugee crisis' should be read within the larger context of the current debates in Germany and Europe about largescale migration of refugees from Syria and other areas of crisis to Europe between 2014-2016. The Angela Merkel-led German government's initial ‘open-border’ policy quickly became the subject of major public controversies about allegedly 'extremely aggressive' North-African migrants, stigmatised as 'Nafris' by German police (Bild 12.01.2016, 'Interne Akte'), and persisting 'rumours' that 'refugees committed serious crimes like rape particularly often' (Focus 17.08.2017, 'Flüchtlinge'). Such suspicion went hand in hand with calls for stricter German immigration laws and the revision of the country's asylum legislation, both of which enabled the fast deportation of migrants originating from countries labelled as 'safe' by the German government (eg. Maghreb states).

The large-scale migration of refugees to Germany was accompanied by a growing popularity of far-right anti-immigrant and anti-Muslim populist organisations such as the PEGIDA movement - an acronym for Patriotic Europeans against the Islamisation of the Occident - and the AfD, Alternative for Germany far-right party. While the established German political parties have suffered major losses in recent elections, the AfD has achieved successes, and to the shock of many entered the national parliament after the 2017 elections (Seongcheol 2017).

In this article, I discuss the extent to which elements of this racialised rhetoric have entered Germany's mainstream media in reports about 'threatening [male] gangs from North Africa', and the labelling of male Muslim migrants as 'an aggressive mob of North-Africans and Arabs, whose archaic image of women and society' would 'not at all fit into German modernity' (Focus 09.01.2016, 'Nacht der Schande'). The image of 
the sexually predatory migrant Muslim man expressed in such narratives has become popularised in discussions about immigration in contemporary Germany. It is flanked by a growing hostility towards Muslim male migrants and Islam. Recent hate crimes by groups of German men targeting 'foreign-looking' migrants in Chemnitz and other Eastern German towns, and public marches of Neo-Nazi groups demonstrate the seriousness of the situation. Public and media imagery of Muslim male migrants not only influence how they are perceived within the context of public agendas set by mainstream media (McCombs 2014), but can also impact on their lives and safety.

The role of feminist groups within this debate can be described as ambiguous. While some German feminist groups have publicly criticised anti-Muslim racism in the current debate and contributed to a counter-discourse, others have openly supported anti-Muslim and anti-immigrant rhetoric. Progressive critical voices within the feminist spectrum have promoted an anti-racist feminism and mobilised social media in the feminist initiative \#ausnahmlos (\#“noexcuses”) 'against sexual violence and racism' demanding that ' $[\mathrm{s}]$ exism and sexual violence must not be portrayed as a problem solely existent amongst certain ethnicities' and that '[i]mages used in the media must not further racist or sexist stereotypes.' (http://ausnahmslos.org/english). These feminist and broader protests stand in sharp contrast to racialised and racist notions of Islam, which have become increasingly common in German public discourse in recent decades Attia 2009). Some critical German media reports also attacked such negative narratives and urged the public to resist the demonisation of Muslim men in the current debate (Spiegel online 02.11.2015, 'Männer, Monster, Muslime').

However, anti-Islam interventions by Alice Schwarzer, the popular editor of the German feminist magazine Emma highlight that anti-Muslim rhetoric is also supported by some feminist circles in Germany (see Dietze 2016, 7; Attia 2009, 64). Schwarzer 
remains convinced, that 'political Islamism' was behind the Cologne attacks with its intention to 'beat up women'(Schwarzer, cited in Dietze 2016, 7). She has openly mobilised against 'the spirit of the politicised Islam' and men from the 'Muslim cultural circle', who treat women as 'subhumans' [Untermenschen] (interview with Alice Schwarzer, 22.6.2016, DW, https://www.youtube.com/watch?v=TXGfoKAoyIc). In this context, Hark and Villa $(2017,92)$ have identified 'toxic intertwinings of feminism and racist respectively anti-Muslim resentments' and concluded that the critique of 'sexism' should never be used for 'a legitimation' of hostile or 'even racist positions' on immigrants.

This interlocking of feminist with anti-Muslim and anti-Immigrant discourse can be interpreted as an example of what Sara Farris has poignantly conceptualised as 'Femonationalism' (Farris 2017; Farris and Rottenberg 2017). It aims to describe both the attempts of western European right-wing parties and neoliberals to advance xenophobic and racist politics through the touting of gender equality as well as the involvement of various well-known feminists and femocrats in the current framing of Islam as a quintessentially misogynistic religion and culture (In the Name of Women's Rights) (Farris, Rottenberg 2017, 8).

Farris and Rottenberg have highlighted and examined problematic alliances between parts of the feminist spectrum, far-right populist organisations and the neoliberal elites. They consider the intertwining of feminism and 'reactionary policies' to be a symptom of Western supremacist hegemonic discourse and link it to neoliberal politics $(2017,8)$. 


\section{The Cologne New Year's Eve events, the 'Othering' of Muslim migrant men, anti-Muslim racism and Islamophobia in the current academic discussion}

The Cologne New Year's Eve events

Recent news reporting about Arab refugee 'Sex mob[s]' allegedly rampaging through Frankfurt and other cities targeted male Muslim migrants as a sexual threat to German women. The German police investigated insult case stories - spread in mainstream newspapers such as the Bild - and criticised different press outlets for having made sensationalist accusations. These media representations culminated in two highly contested openly racist and sexist newspaper images published in the leading liberal newspaper Süddeutsche Zeitung and the political magazine Focus in the aftermath of the Cologne New Year's Eve events in 2016. The first image in the Süddeutsche Zeitung depicted a white female lower body with a black arm reaching between her legs. The second image published as a Focus title page showed a slim naked white female body covered with black handprints. Its' caption made German 'women accuse' and asked provocatively whether the German people were 'still tolerant or already blind after the sex-attacks of migrants' (see figure 1).

There is evidence that at least some of these media claims are fabricated and false. A recent alleged sexual assault incident story from Frankfurt for example, reported in Bild, involving allegations against fifty male Arab refugees (all thought to be Muslim) accused of sexually threatening women in a restaurant on New Year's Eve 2017, has now been taken off the newspaper's website after police found the newspaper's allegations to be 'without foundation'. Other media claims were, however, rooted in reality. he sexual attacks on German women during New Year's Eve 2016 in Cologne and some other cities were undoubtedly violent, offensive and sexist, and it was crucial for German authorities to follow these up. 
Different researchers have argued that the wider public and media in Germany failed to properly reflect on the Cologne attacks in the context of widespread everyday sexism in Germany by representing these crimes as the sexual outbursts of a different type of man, the Muslim migrant, and his allegedly threatening sexuality. Stöckle and Wegscheider (2016) addressed sexual harassment as a common problem for women, highlighting that ' $[\mathrm{t}]$ he perpetrators are almost always men' without any 'significant distinction according to religion, background, educational level or social status'. Other researchers too have criticised the rise of anti-immigrant sentiment in Germany and a public image of Muslim migrant men that ethnicises sexual violence and fosters antiMuslim racist rhetoric.

Dietze's literature-based essay reflects on the 'event Cologne' as a case of 'Ethnosexism' (2016a, 1) linking racism and sexism (2016b). Drueke has shown in an empirical study of public television in Germany (2016) that their reporting also generally failed to conceptualise sexualised violence as a broader societal issue. Hark and Villa have in a critical feminist essay identified problematic interlockings of feminist perspectives, racist and anti-Muslim rhetoric after the Cologne events (2017). Weber has in two shorter reflective pieces suggested similarly that the New Year's Eve violence had sexualised dimensions to mobilise fears of the Muslim 'Other' (2016a), while ignoring sexual violence as a pre-existing problem in European society (2016b). As shown, previous researchers have identified some links between racism, sexism and religion in the current German public debate about migrant men and have occasionally referred to the media in this debate. However, given their different main research foci, most of them have not offered in-depth and systematic analysis of media representations of male Muslim migrants in the aftermath of the Cologne attacks. 
This research examines how Muslim migrant men have been constructed as marginalised 'Others' to German mainstream society in German mass media. The concept of 'the Other' is associated with Hall's (1997) ground-breaking work on the historical evolution of discursive racialised Othering in Western society. Pickering has also shown how Western society, in the context of colonialism and hegemonic discourses of white normativity, has constructed multiple 'stereotypical others'. He has suggested that mass media play a key role in the promotion and popularisation of racialised images of 'the Other' (Pickering 2001). Furthermore, Smedley (1993) has demonstrated that European representations of racialised others were linked to a pseudo-scientific Enlightenment race discourse and posited that hierarchical race theories grounded in an ideology of white superiority became a world-view in $19^{\text {th }}$ century Europe. Contemporary representations of Muslim migrant men as 'Others' and sexual predators in German media echo a reservoir of racialised anti-Muslim and antiblack narratives with a long history in German society and beyond and must therefore be seen in historical context. Attia's work has examined the interlinking of gender narratives and orientalist anti-Muslim racism with reference to Edward Said and postcolonial studies (2007). She has criticised the association of patriarchy and sexism with 'oriental-Islamic' culture and the inferiorising Othering of Islam in Western discourse $(2009,152)$. Such imagery is grounded in the colonial history of Orientalism (Said 2003) and anti-Muslim racism in Europe. It reproduces age-old racialised stereotypes of 'coloured men' as threatening outsiders in the West, and as dangerous sexual predators, targeting European ‘white women’ with their allegedly un-tamed sexual desires. German history and the construction of a German 'white' identity has clear racist dimensions and has produced a wealth of racialised imagery of foreign black 
and oriental men with allegedly threatening sexual vices (eg. Hund 2017; Author 2010, 2017).

Islamophobia has become an increasingly prevalent problem in Western Society (Esposito, Kalin 2011; Meer, Noorani 2008) and its links to racism have been discussed in contemporary research (Meer, Noorani 2008; Bleich, Stonebraker et al 2015). The latest Runnymede report suggests that the term Islamophobia has 'led to some confusion', and should be conceptualised as a form of racism, arguing 'Islamophobia is anti-Muslim racism.' (Elahi, Khan 2017). This perspective resonates with other scholars' attempts to explore religion in the context of 'racialisation' (Meer 2013). It highlights the 'racialized dimension to Islamophobia' and 'the construction of Islam as Other (Taras 2013, 419). These and other scholarly works critically discuss an increasing normalisation of Islamophobic discourse in contemporary society (Cohen,Tufail 2017), examining it as 'a form of, and alibi for, contemporary racemaking' (Alexander 2017, 15). Allen (2010) has examined the historical genesis of Islamophobia in Western society and discussed the active role of the media in its construction and reproduction.

Othering is a prominent theme in Islamophobic and Anti-Muslim discourses. Goldberg $(2006,345)$ argues that Islam is constructed as the essential 'Other' to Europe and its core dispositions and values within the dominant European imagination, while Nyhagen and Halsaa $(2016,61)$ note that the construction of Muslims as 'others' in Europe creates symbolic boundaries between those who are seen to 'belong' and those who are regarded as outsiders. Both religion and migration are central to the politics of belonging played out in Western Europe (ibid.). This article advances these sociological conceptual discussions, by exploring the stereotypical Othering (Pickering 2001) of Muslim migrants and the intersecting of narratives of difference (Author 2017) in their 
media representation in an empirical case study. It proposes an original theoretical concept, that of 'intersectional stereotyping' based on the interplay between racialised, gendered and religious patterns of discrimination, thus making an innovative contribution to the field of media stereotyping and critical studies of religion, 'Othering', anti-Muslim racism and Islamophobia. The following section outlines this analytical perspective further by exploring its foundations in Stuart Hall's analysis of media stereotyping and black feminist discussions on intersectionality. It builds on intersectionality 'in action' as developed by feminist theorists and extends intersectionality by combining it with stereotyping as the conceptual lens of 'intersectional stereotyping' and applying it to media representation.

\section{Intersectional media stereotyping, Anti-Muslim racism and the social construction of difference: a theoretical framework}

Stereotyping is a common feature of media discourses. Hall has examined the media as a 'powerful source of ideas about race' $(1995,20)$ and critically reflected on an arsenal of stereotypical 'racialized representation in western popular culture' $(1997,269)$. He understands stereotyping as a representational practice, which constructs binary oppositions as it 'reduces, essentializes, naturalizes and fixes "difference"' to maintain 'social and symbolic order' (257f.). Hall explores racialised stereotypes from a discursive perspective, examining how meaning is produced through 'language and representation.' He argues that discursively produced knowledge is linked with power, 'constructs identities and subjectivities', and defines how we represent and perceive 'certain things' (Hall 1997, 7).

His important case study on the discourse of the 'black mugger' (1978) examines the interlocking of narratives of race, crime, youth culture and identity in moral panics associated with young black people in British 1970s society and analyses 
the role of media in steering public debate. Hall's image of the black mugger as a 'Folk Devil' in British media reporting onto whom wider social fears about security and a fragile, failing society could be projected shows strong parallels with current German media imagery of male Muslim migrants as aggressive and threatening criminals and sexual perpetrators causing chaos in German cities.

'Intersectionality' as a theoretical perspective is associated with the work of black feminist theorists. For Kimberlé Crenshaw (1989) it addresses how an individual or group suffers from multiple forms of marginalisation, oppression and discrimination, e.g., black women in American society facing multiple discriminations based on gender, race and class, compared to white women. It has thrived as a key theoretical framework in critical sociological research, used to analyse multiple categories of difference (gender, race, ethnicity, class among others) and reveal their close intertwining to make sense of inequalities within our social world. The intersecting of multi-faceted social inequalities and narratives of discrimination has become a popular subject in different fields in the last decades, including racism analysis, feminist analysis, migration studies and postcolonial studies (eg. Anthias and Yuval Davis 1993). It can be argued that Muslim male migrants are discriminated against in German society due to their status as both migrants and Muslims. However, my article builds further on this by showing that Muslim migrant men in German media discourse are subjected to a process of what I have coined intersectional stereotyping. This concept is proposed as an analytical tool that conceptualises the complex intertwining of categories of difference (associated with socially constructed narratives of e.g. 'race', sex, gender, nation, religion) in media stereotyping. It aims to capture and analyse intersectionality 'in action' on the discursive level of media representation. 
Intersectional stereotyping draws on the original definition of intersectionality as developed in feminist scholarship and extends it. The main difference between the common uses of the term intersectionality and my concept of intersectional stereotyping is that intersectionality traditionally refers to a membership of multiple socially constructed categories that those concerned often acknowledge, to some extent identify with and adopt as an active political identification, whereas intersectional stereotyping refers to a largely false ascription of membership of disrespected negatively labelled categories to those who are (genuinely) members of the (possibly already intersectional) category being stereotyped - in our case migrant men with Muslim backgrounds. While intersectionality usually refers to acknowledged membership of the intersecting categories, intersectional stereotyping captures how further negatively connotated categories are discursively added to the intersection that misrepresent the group portrayed - for example by labelling them as criminals.

Intersectional stereotyping hereby draws on simple forms of stereotyping - e.g. Islam is associated with backwardness - and then builds up more intersectional stereotypes - eg. Media reports associate young Muslim men with religious, racialised and gender stereotypes, which leads to stereotyping them as aggressive sexual criminals. Simple stereotypes also involve linking a group discursively with negatively labelled attributes that misrepresent them; they become intersectional stereotypes when multiple characteristics are interlocked and conglomerated in the stereotyping narrative.

Intersectional stereotyping can hence help us to critically deconstruct the intersecting of categories of difference in media stereotyping of migrants and other discriminated groups. It enables us to critically examine how the stereotyped group (in our case Muslim migrant men) is linked to multiple categories that are negatively labelled, despised, or feared, or constructed to be so in media representations. In this 
context male Muslim migrants are discursively constructed as criminals as well - not only in the particular cases of those male migrants who actually commit an offence but as a form of negatively labelling all Muslim male migrants. They are also represented as sex offenders or sexual harassers and hence associated with two particularly despised categories in contemporary societal discourse. Below, I show that this representation is highly problematic, as it racialises and 'others' all Muslim male migrants as criminals and harassers. Furthermore, I argue that sexism is a general problem that exists among all ethnic and religious groups, and that the vast majority of these migrant men are not criminals/harassers. I aim to demonstrate how this media discourse forms a racialised, gendered and religionised stereotype combining the narrative of male Muslim migrant with that of sex offender/criminal, which is then employed to promote anti-immigrant and anti-Muslim populism.

This study conceptualises the media representation of Muslim migrant men in German newspaper and magazine articles as intersectional stereotyping to conceptualise how intersecting narratives of difference form a stereotype that interlinks racialised sexual violence associated with Muslim migrant men with a gendered and anti-Muslim form of racism. Ideologically grounded in Orientalist and Western colonial imagery of coloured men as sexual perpetrators, it targets Muslim male migrants as sexually threatening criminals and 'Others', and associates their alleged deviance with Islam. The theoretical argument that frames this article is inspired by Stuart Hall's conceptualisation of 'race' as a 'discursive system' grounded in social, political and economic relations (Hall, cited in Solomos 2014, 1670) - and closely associated with processes of racialised Othering within a Western colonial discourse, underpinned by a hegemonic and normative racist white imagination. 
Hall (1995) rejected the concept of race as a natural essentialist category and promoted its critical analysis as a discursively constructed category of difference. Talal Asad (1993) has discussed religion as a socially constructed category of difference. His analysis of the development of religious ideas in modern history has demonstrated that 'there cannot be a universal definition of religion, not only because its constituent elements and relationships are historically specific, but because that definition is itself the historical product of discursive processes' in the genesis of modern society (Asad 1993, 29). Similarly, categories of gender and sexuality have also been argued by feminist scholars to be socially constructed and constituted within discourse (Butler 1990).

My analysis of the representations of Muslim migrant men in the selected media outlets follows this social constructionist, discursive perspective by examining the categories of difference identified in the German media discourse (eg. race, gender, religion) as socially produced. In contrast, however, the analysed media materials treated these categories predominantly as essentialist 'natural' categories often reproducing existing negative societal perceptions and stereotypes of difference and otherness associated with migrants in German society.

\section{Materials and Methods}

This study focused on the three major German newspapers Frankfurter Allgemeine Zeitung (FAZ), Süddeutsche Zeitung (SZ), Bild and the political weekly magazine Focus. The rationale for choosing these outlets is grounded in their popularity, marketleading role and circulation in Germany. The sample covers the period from May 2015 to January 2017, and was collected in a digital data search based on a keyword search matrix, searching words including refugee, migrant, migration, sex, and violence, 
Muslim and Islam. ${ }^{1}$ The current sample of thirty-two articles has been selected for its illustrative value following a quantitative content analysis of a larger data corpus of 407 articles, using formal coding to identify the prominence of different themes and actors in these media outlets' reporting on migration. It is typical of the larger sample.

The chosen media outlets differ regarding core thematic areas covered as well as their political orientation. The $S Z$ is a leading paper of the liberal spectrum with a strong cultural and social focus. In the first quarter of 2016 its print version had a circulation of 382.050, together with 9.9 million page views for the online version in March 2016.

The $F A Z$ is a core conservative newspaper with a major focus on economy and politics. It sold 252.676 copies daily in the first quarter of 2016 plus 254.291 of the Sunday version, and its' digital online version reached 7,68 million people in March 2016. The Bild is Germany's largest tabloid and most popular newspaper selling 1.882 .473 copies and reaching 17,74 Million readers with its' online newspaper in March 2016. It has been frequently criticised for its sensationalist style of reporting. The weekly Focus is one of the highest-circulated German news magazines and seen as conservative. In the first quarter of 2016 it sold 474,285 print copies and the Internet version reached about 18,55 million people in March 2016. The Focus was included in this sample, as an interesting and in the context of media representations of migrants under-researched magazine, even though the circulation of other German magazines (eg. Der Spiegel and Stern) are higher. The Focus was also directly involved in promoting contested imagery of migrants in the aftermath of the Cologne events when publishing a title page that linked the 'sex attacks of migrants' to the image of a naked white female body covered in black handprints (see figure 1).

\footnotetext{
${ }^{1}$ We searched for articles in this period to include the reporting during the 'European refugee crisis' before and after the Cologne New Year's Eve 2016 assaults.
} 
The analysis of the data sample focused on the reporting of migrants, sex and sexual violence, which as the key themes shaped the examination of the data. The study addressed the following three research questions:

(1) How do mainstream German print-media write about Muslim migrant men and what role do narratives of race, gender, sex, religion and violence play in their representation?

(2) To what extent do concepts of race, gender, sex and religion intersect in stereotypical perceptions of male Muslim migrants promoted in mainstream German print-media?

(3) What does the structure of these media narratives tell us about underlying stereotypes associated with Muslim migrant men and the wider, social, cultural, political and historical context of these stereotypes?

I read the articles first using a screening technique, and then identified common reoccurring concepts in a second in-depth reading. These were in turn categorised into three major themes: 1. Links between the migrants' gender, sexism, sexual violence and religion; 2. Migrants as 'Others' in German society/Europe based on their religion, behaviour and culture and 3. Muslim migrants as criminals threatening German society. I also identified occasional positive references to migrants in the data sample, including critical reflections on sensationalist media stories and stereotypes of migrants. These will be discussed in relation to the three themes as they highlight ambivalences and different editorial lines within the reporting and show that media itself has the potential to develop a critique of stereotypical reporting about migrants.

\section{Findings}




\section{Sexism and sexual violence perceived as problems of patriarchal Islamic culture}

The first major theme in the data sample relates to repeated attempts to link sexism and sexual violence closely with migrants, their gender, religion and 'Islamic culture'. After the Cologne New Year's Eve events from 2016, several articles reported on 'sexual crimes' of migrant Muslim men, the 'running the gauntlet' of targeted German women and other 'shocking' details (Süddeutsche.de 07.01.2016, 'Spiessrutenlauf'). Germany was presented as under siege by 'terror, refugee chaos and the hunt for women in German cities' (Focus 16.01.2016, 'Wohin mit den Menschen?'). Many news reports focused on the 'Nafris', a controversial police label associated with crime, and considered them 'extremely aggressive' (Bild 12.01.2016, 'Interne Akte'). A Focus article from January 2016, for example, refers to a 'chronology of horror in Cologne' (20.01.2016, 'Übergriffe in der Silvesternacht') and reports about 'North-African violent criminals (Nafris)' who were entirely 'disinhibited', and accused of 'assault on a sexual basis', 'violent rape' and 'theft'. Another Focus article from the same period reports outrage about 'sex-attacks against women' and other crimes. Nightmarish 'sexual attacks', 'hunting scenes' and other acts of violence and theft are linked to Germany's acceptance of over a million refugees in 2015, which allegedly prompted the 'collision' of ‘completely alien' opposed 'cultural circles' (09.01.2016, 'Nacht der Schande').

The Focus cited a German expert on Syria, who associates 'young Arab men' with 'a culture of violence' warning that - given the great numbers of 'refugees' who have come to Germany - the 'atrocities of Cologne New Year's Eve' could just have been the 'first taste'. He uses the Cologne events as evidence, even though, as the article notes correctly, 'the majority of perpetrators' came 'from North-Africa - not from 
Syria' and claimed that the 'sexual attacks' of 'young Arab men' not least aimed at 'the European man, whose honour the Oriental wants to tarnish'. Arab migrants are hereby associated with an 'oriental-patriarchal culture' and accused of seeking revenge against Europeans out of 'envy' (Focus Online 02.02.2016, 'Kultur der Gewalt').

These articles link sexism and sexual violence with male migrants and their religious background. Sexual violence and the domination of women are thereby turned into a characteristic feature of Muslim migrant men and are portrayed as an essential dimension of their religious beliefs and 'backward' patriarchal Islamic culture. Hereby it is implicated that the Arab Muslim male migrant represents an altogether different and threatening type of man compared to 'civilised' (secular) European men. He is hence placed in a binary opposition to the latter, and portrayed as the envious 'Oriental' man, aiming to humiliate and dishonour the 'civilised' European man.

Such attempts to racialise and islamicise sexual aggression and violence form a prominent pattern in the analysed newspapers articles. They narrate Muslim male migrants stereotypically as 'Others', who are culturally alien to modern German society and its progressive civilised European values and who predominantly target nonMuslim women. A FAZ article focuses in this context on 'sex and the city' as consequence of the sharply increasing population in North-Africa. It nostalgically remembers life in Cairo in the first half of the twentieth century, when its educated middle classes developed a culture imitating the 'lifestyle of Paris and London' on which 'the Arab world' would still feed. It seemed clear that 'the intellectual standard was higher than today' with religion 'practiced in the private sphere' predominantly and women 'strolling about in European costumes', with 'no one coming on to them'. In contrast, today's overpopulated North-African cities seemed filled with poor people, 'generations of sexually frustrated young men', who had to delay marriage due to a lack 
of financial resources. This problem would be visible in Cairo's metro, where 'for women a journey without sexual assault' was 'impossible'. The author portrayed 'sexual assaults - preferably against non-Muslim women, but also against Muslim women' as 'a way out of sexual frustration' or 'homosexuality' to conclude that Islam would not provide any realistic advice to the young sexually frustrated men (FAZ, 12.01.2016, 'Arabische Domplatte').

The Eurocentric, culturally chauvinist tone of the above article is obvious. It is neither accidental nor coincidental, but symptomatic of a long Western tradition of Othering and down-grading non-European people and cultures as essentially inferior to European cultural standards and values. This tradition originates in discourses of Western cultural hegemony, colonialism, Orientalism and white normativity, which underlie European perceptions of the 'Self and Other'. Against its background, the current 'North-African' world is here placed below European culture and secularism, as a place of failed modernisation, breeding structural 'poverty', religious dogma, and 'sexual frustration'. Interestingly, class is here mobilised as another category of difference to paint an inferiorising picture of Muslim migrants, whereas it was not a common category of reference in the analysed data corpus. Different articles did however, include similar 'expert' opinions in their portrayals of sexual violence as an expression of the Muslim migrants' Islamic patriarchal culture

Such reports about migrant Muslim men as serial sex offenders based on fundamentalist patriarchal views are sometimes contrasted by media reports that promote a more sympathetic perspective and emphasise their positive qualities, humanism and, in one case, helpfulness as preventers of sexual crime. A FAZ article from summer 2015, for example, positively reports about a newly founded 'German Muslim forum' wanting to 'give a voice to the humanistically oriented Muslims' (FAZ 
22.06.2015, 'Der Islam'). Other articles reflect positively on how 'theology and pedagogy can provide a better alternative to young Muslims' opposing the 'preachers of hatred' (SZ 30.01.2016, 'Theologie und Pädagogik') or praise a Syrian refugee, who saved a female US student from the Cologne Sex-Mob presenting a photo with both of them looking 'like old friends' (Bild 18.01.2016, 'Kölner Silvester-Schande’).

\section{The representation of male Muslim migrants as 'Others'}

Media representations of sexual violence as an essential expression of male Muslim migrants' religious and cultural background are an important element in wider media attempts to depict them as 'Others within' and strangers to Germany, Europe and the Western world in general. This is the second main theme identified in my analysis.

A guest-authored Focus article on the 'refugee crisis' and the 'stream of refugees, especially from the Islamic cultural circle', illustrates the Othering theme rather well. Even though its author claims to promote 'a differentiated perspective', he is concerned, about the hundred-thousands young men belonging to 'Arabian Islam', as they were likely to overstrain German society. Germans should not have to justify their 'traditions' and 'free society' to the new arrivals. While acknowledging, that 'some educated and vocationally trained people' have arrived in Germany especially from Syria, the author warned that many were entirely 'without any qualifications' and would 'massively strain our social welfare systems'. Referring to a letter about the situation in a refugee camp in Hessen, he stated that migrant men "'allocate them [women] an

inferior role"”, while considering "“women travelling on their own as fair game"”. This would result in "“sexual atrocities"” and "'rape"'-as a common problem. '[S]uch conditions' would merit an unrestricted 'objective critique' (Focus Online 23.09.2015, 'Flüchtlingskrise'). 
This portrayal of migrant Muslim men as representatives of a religion of backward and patriarchal outsiders, unfamiliar with the basic rules and values in modern German society can also be found in other media reports. In the FAZ, for example, a German conservative MP insisted that Muslim refugees in Germany had to 'understand that they have not arrived in a value-neutral societal system.' 'Integration' was not to be mistaken as 'random Multi-Culti' but it was to be acknowledged 'that Germany is as successful as it is, because it is an enlightened country, in which the basic core values are not negotiable'. The picture of the migrant Muslim man is here based on assigned religious values positioned in direct opposition to this portrayal of Germany as a superior value-based community and hegemonic culture. The 'equal rights of men and women' for example would demonstrate that 'family honour' in German society did not depend on 'with whom one's daughter has sex' and girls here would join 'class trips' and 'swimming lessons 'whether or not this fits with religious convictions'. Migrants also needed to 'accept, that the father too could look after a child, when the mother attends a language course'.

When the interviewer remarked critically that such acceptance was 'uncommon in Germany until recently' too and asked the politician how conservative refugees were allowed to be, the MP drew a sharp ideological line between 'being 'conservative' on the one hand, and showing a 'religious-fundamentalist attitude' on the other. The religious fundamentalism assigned to Muslim migrant men marks them as essentially different 'others' - patriarchal outsiders within the decisively more equal progressive German cultural community. There would be a clear difference between the apparently acceptable fact that 'in Germany the women' had 'not arrived on all levels of leadership' and the unacceptable Muslim man who did not 'shake a woman's hand, 
because he considers her impure or believes that women have to fully veil themselves' (FAZ Sonntagszeitung, 03.01.2016, 'Die Ressourcen').

Another article in the Bild commented on 'the Sex-Mob debate' and encouraged Germans to 'explain why our model is better than everything the Arab-Muslim world' had ever 'produced'. This stereotypical racialised Othering of male Muslim migrants as representatives of a monolithic Muslim religion which is placed in binary opposition to core Western values is highly problematic, not least as it rhetorically feeds Huntington's and current far-right populist outcries about an alleged 'clash of civilisations' and fixates Muslim culture as not only different, but inferior, directly opposed to, threatening and undermining German and wider Western society. Such idiosyncratic rhetoric of an Islamic culture inherently incompatible with European society and its core values is Islamophobic and historically illiterate, but it seems has become publicly acceptable again in recent years especially in the light of the so-called 'refugee crisis'. Attempts to question it are often dismissed as 'political correctness'.

The Focus article 'We are defending Europe's values' illustrates this perspective further. It argues that migrants from Africa and parts of Asia only had 'limited' 'development prospects', referring to a Chemnitz 'study', according to which the average IQ of 'Asylum seekers' with a University degree was comparable with that of German Middle-school (GCSE level) students. The author attributed them with high levels of aggression and a 'fundamental lack of competence', intensified by 'Muslim communities and the common practice in Africa of marriage between relatives'. The rate of unemployment and benefit seekers was deemed to be 'higher' among them, and they were accused of misjudging their own 'cognitive errors' as 'discrimination'. Rather than taking up 'alternative goals', some would focus on 'dysfunctional' options, like 'criminality or the focus on religion' (Focus, 17.10.2015, 'Werte Europas'). 
While negative stereotypes are dominating media reporting on migrants as outsiders in German society, we can also find occasional positive elements in their representation in relation to their attitudes and potential for integration. A German minister in Hessen for example acknowledged that 'most of the recognised refugees' show a 'great will for integration' into German society, and are keen to learn German, as required to get a job (FAZ, 17.01.2016, 'Zahl der Flüchtlinge'). Another newspaper reported positively about the development of an 'Enlightened Islam' in Germany, reflecting on the recent 'Freiburg declaration' of 'liberal Muslims' who want to 'reconcile their faith with the German Leitkultur' (Focus, 22.10.2016, 'aufgeklärter Islam') and the SZ referred to migrants from 'North-Africa' who have lived in Germany peacefully and 'extremely well integrated' for generations (SZ 12.01.2016, 'Tatverdächtige'). Such positive references to migrants' keenness to integrate contrast with stereotypical perceptions of them as essential 'Others' incapable to integrate based on their alleged backward, patriarchal and fundamentalist Muslim values. They show that the media portrayal of Muslim migrants can include more critical and differentiated reporting. This implies that the German media do not speak with one voice, as different outlets have different editorial policies. Moreover, different writers and columnists have different perspectives even within the same outlet, and the SZ is, for example, on balance noticeably more sympathetic to migrants.

\section{The representation of male Muslim migrants as criminals}

Frequent portrayals of Muslim migrants as delinquent essential Others who undermine Western values cumulate in the suspicion that they have created a parallel society in Germany. Criminality and violence are closely associated with the Othering theme in the sample. Media reports represented Muslim migrant men as perpetrators, who were 
causing enormous problems, demanded a 'hard hand' against them and promoted calls for a faster, more rigorous asylum-process, and prompt deportation of all 'illegal immigrants'. Reports framed male Muslim migrants as an underestimated threat to German society, and its' police, government and media were accused of failing German citizens by either ignoring, down-playing, or 'distorting' (Focus online 17.02.2016, 'Problem mit "Nafris"') information about migrants and crime.

A Focus article referred already before the Cologne events to 'a large number of reports about violence within migrant families $[\ldots]$ including sexual atrocities, sometimes in the form of eruptive violence of whole city districts.' Violence was claimed to be directed against 'other migrants, women, native citizens, political opponents and people of different beliefs'. The academic 'expert' author used these claims to associate migrant groups stereotypically with 'a considerably higher aggression' visible 'across situations, countries and periods of time'. He explained that their 'criminality' would be linked to 'internal factors, such as culture and practice of Islam in the countries of origin', playing 'a big role' together with 'frustration'. He claimed with reference to different European countries that 'Muslims' are 'overrepresented' in 'violent crimes' and 'rapes' to conclude that 'migration' would lead to more diversity. Diversity is hereby constructed negatively as 'linked to more inequality in income, fragility of the state, higher rates of crime' and compromising 'the freedom and everyday life of women [...]' (Focus 17.10.2015, 'Europas Werte').

Other articles too, speculated that 'the police' were 'forbidden to say the truth' and expressed concern about a 'conspiracy of silence' and the existence of Muslim parallel societies (see e.g. Bild 08.01.2016, 'die Wahrheit'; Focus 10.10.2015, 'Schweige-Kartell'). A German conservative minister explained that, in the context of migrant sex crimes, German people could expect that migrants 'who are living in 
Germany as guests' and become heavily delinquent will be deported consequently. Those who seek 'the protection of the constitution' needed to 'show consideration for' the constitution. Moreover, the legal punishment for 'sexual crimes' was to be toughened and measures of integration such as compulsory 'integration courses' needed to be intensified (FAZ, 17.01.2016). The Bild echoes these concerns in an article about a political talk show on German television titled 'refugees under suspicion, citizens unsettled: Angst republic Germany'. The newspaper was convinced that Cologne New Year's Eve still 'echoes' two weeks after the Cologne incidents, while 'politics and police' appear 'powerless' and concluded that 'many citizens have lost their trust in the German state and its rule of law' (Bild 14.01.2016, 'Terror gewöhnen').

An SZ article in contrast followed a different, more nuanced, pro-migrant editorial line when reflecting on the issue of Muslim 'parallel societies' and migrant integration in Germany. It referred to an expert who stresses that migrant 'families and clans with extreme traditional or religiously determined internal social control' are a 'small phenomenon' and that this problem cannot be associated with 'THE Turks or THE Muslims'. The author warned about a 'segregation' of migrants within German society and criticised 'mainstream society' for not showing enough 'interest to integrate migrants', and for 'perceiving' and 'excluding' 'them as a homogenous unit of strangers' (Süddeutsche.de 10.08.2016, 'Parallelgesellschaften'). A Focus online article similarly considered the popular 'assumption that young refugees would be more ready to use violence' as 'unsubstantiated' based on data from the BKA - the German national crime agency and an expert criminologist explained that 'violent crime rates' have 'decreased, even though so many refugees arrived'. The article urged its' readers to view 'the problem of sexualised violence' in broad perspective and reflects on some typical 'post-traumatic' issues of refugees, to conclude that they are in principal as 
'traumatised people endangered, not dangerous'. Young refugees would 'behave like young German men' and it would hence be wrong to relate single isolated cases of violent crime to the 'refugee problematic'. The article referred to the case of a young male refugee from Afghanistan, under suspicion of having raped and murdered a young woman in Freiburg. Comments from its' readers however, expressed outrage, calling the article a 'disgusting propaganda' of 'infamous lies' and insisted that 'non-Germans are more dangerous than Germans' (Focus online 06.12.2016, ‘junge Flüchtlinge').

These readers' expressions of dissatisfaction, hostility and outrage in reaction to the article's argument that migrant men are, according to recent official statistics by the German National crime agency (BKA), not more likely to become violent than German men, show us the wider societal brisance of these issues. In maintaining a variegating perspective, it is important to reflect critically on the Cologne sexual offences and to recognise violent sexual crimes of this nature as an issue in contemporary German society. In this context we can see - without dismissing all criticism of Muslim migrant men as racist - that the suspicion that they are typically and in large numbers criminals and sexual perpetrators based on their religious attitudes is unsubstantiated. The BKA German National crime agency's data on the subject published in summer 2016 show that immigrants in Germany are not more likely to be criminal than German men. Even a BILD journalist acknowledged this in a rare 'Bild-Facts-check on refugee criminality' article which contrasted with the newspaper's frequent sensationalist, stereotypical reporting on the subject. The journalist referred to the BKA data, but concluded that 'experts are doubting the meaningfulness' of the newly published BKA statistics (Bild 10.06.2016, 'Bild-Fakten-Check').

\section{Discussion}

Sexism and sexual violence feature prominently in the German media portrayal of 
migrants where they are directly associated with male Muslim migrants' religion and patriarchal Islamic culture. This close interweaving of sex, religion and alien status in the intersectional stereotype of the Muslim migrant man racialises sexism and resonates with a wider anti-Muslim discourse within contemporary Germany and Europe and its attempt to ethnicise, islamicise and essentialise sexism. The claim that migrant Muslim/Arab men are 'naturally' more aggressive, sexually violent and culturally backward based on their religious background is racist in its connotations.

Narratives of race, gender, sex, religion and violence were shown to be closely linked in the media reports about migrant Muslim men. Sexism however, was not imported into Germany when it decided to temporarily open its borders to refugees; it remains a persistent homemade patriarchal issue, which has affected the lives of women in German society and across the globe for centuries. Media portrayals of male Muslim migrants as sexual perpetrators also resonate with historically deep-rooted popular racist imagery of black men as representatives of a 'primitive and savage race', who violate and rape German 'white women'. Such imagery was for example at the heart of the 1920s popular 'Black Horror on the Rhine' campaign, which dehumanised French Black colonial soldiers as 'brutal beasts' with dangerous sexual instincts and racialised them as a primitive threat to German women, the German nation, and 'white civilisation', accusing them wrongly of sexually violating 'white German women' on a large scale. Narratives of coloured men as sexual perpetrators are fuelled by and reproduce an age-old popular Western race discourse and well-established racist stereotypes of black primitivity and black male aggressive and 'untamed' sexual impulses (Author, 2017).

The narrative of the migrant man as a sexual threat to 'German white women' is an important element of a wider, over-arching Othering theme identified in the 
intersectional media stereotyping of Muslim male migrants. They are predominantly perceived as outsiders within, as 'the enemy', and are under suspicion to have formed a parallel society in Germany with their patriarchal, alien and backward religious and cultural traditions. The German police are accused of not acting efficiently on migrant crime, and the government is criticised for allegedly letting the 'immigration problem' spin out of control.

Different newspapers predominantly portray migrant men as violent and criminal 'Others' and as a threat to German society, associating violence directly with their Muslim background. The image of the criminal Muslim migrant is a core element in an Othering process that echoes and reproduces popular stereotypical perceptions of migrant men as criminal offenders in the context of an increasingly popular anti-Muslim racism. Looking at the concerning rise of far-right populist organisations in Europe and the USA, we should as a society become critically aware of the need to avoid cultural generalisations and discreditations of this kind, and to report about cultural diversity in a well-differentiated manner. The monolithic claim of a single 'Islamic culture' and the Muslim migrant is problematic, as Islam is made up by a variety of people with a spectrum of personal beliefs and cultural and religious identities. The assumption that Islam is essentially incompatible with European culture is historically flawed (see Attia 2007).

This article has demonstrated how dominant lines within the media reporting about migrant Muslim men in Germany formed an intersectional stereotype. Its deconstruction can help us to analytically decipher the intersecting of complex stereotypical narratives in the media reporting about this group. Media narratives of Muslim migrant men as sexual perpetrators and criminals based on a cultural 'Muslim' backwardness have been shown to be linked to existing cultural stereotypical 
perceptions of Arab Muslim men and Islam in German society, which are grounded in Western Orientalism, colonialism, cultural imperialism and domination. We have seen that they can also build upon wider established racist stereotypes of black men in Western society as racially primitive sexual perpetrators, embedded in a long history of Western racialised colonial imagery of colouredness/blackness. A critical reflection on such historical continuities in media representations of migrant Muslim men can help to deepen our understanding of contemporary media stereotypes associated with them and the intersecting of racist, sexist, religious and ethnic narratives in them. The image of the migrant Muslim man as a stereotypical Other, who is inferior, primitive and dangerous has clear orientalist and racist connotations and constructs him in direct binary opposition to Germany, and the Western hegemonic self-image as a superior, advanced and civilised society of shared progressive values.

The identified positive lines of reporting clearly contrast, and sometimes overlap, with negative, stereotypical reporting, while promoting a more positive outlook and sympathetic view on Muslim migrants and a more nuanced, reflexive perspective on the discussed three major themes - sexual harassment, Muslim migrants as Others, and crime. On balance, however, it is evident that the German media predominantly favour a negative, and in many cases anti-immigrant and anti-Muslim perspective in their reporting. Positive reports seem to mirror a current societal trend of fact-checking, but remain marginal compared to the majority of negative reports. At the same time, it is vital to acknowledge these contrasting perspectives within the German media, as they illustrate that the popularisation of stereotypes of Muslim men in the media portrayal of migrants is contested within German society and can be seen as part of what Stuart Hall has described as a discursive 'struggle over meaning'. Together with some feminist and other critical progressive initiatives some media voices are clearly attempting to resist 
drawing upon stereotypical perceptions of Muslim migrants and critically reflect on these. Their public challenges to the racialisation and islamicisation of sexual violence are long overdue.

\section{Declaration of interest statement}

The author declares no potential conflicts of interest with respect to the research, authorship, and/or publication of this article.

\section{References}

Alexander, Claire. 2017. Raceing Islamphobia. In Islamophobia: Still A Challenge For Us All. A $20^{\text {th }}$ Anniversary Report, Runnymede Trust ed. Farah Elahi and Omar Khan, London: Runnymede Trust, 13-16. Available at: https://www.runnymedetrust.org/uploads/Islamophobia\%20Report $\% 202018 \% 20 \mathrm{FINAL} . p d f$

Allen, Chris. 2010. Islamophobia. London: Ashgate.

Anthias, Floya, and Nira Yuval-Davis. 1993. Racialized Boundaries: Race, Nation, Gender, Colour and Class and the Anti-racist Struggle. Abingdon: Routledge.

Asad, Talal. 1993. Genealogies of Religion. Discipline and Reasons of Power in Christianity and Islam. Baltimore and London: John Hopkins University Press.

Attia, Iman. 2009. Die Westliche Kultur und ihr Anderes. Zur Dekonstruktion von Orientalismus und antimuslimischen Rassismus. Berlin: Transcript.

Attia, Iman. 2007. Orient- und IslamBilder: Interdisziplinäre Beiträge zu Orientalismus und antimuslimischem Rassismus. Münster: Unrast.

Bleich, Erik, Hannah Stonebraker, Hasher Nisar, and Rana Abdelhamid. 2015. Media Portrayals of Minorities: Muslims in British Newspaper Headlines, 2001-2012. Journal of Ethnic and Migration Studies 41 (6): 942-962

Butler, Judith. 1990. Gender Trouble. New York: Routledge.

Cohen, Barbara, and Waqas Tufail. 2017. Prevent and the Normalization of Islamophobia.

In Islamophobia: Still A Challenge For Us All. A $20^{\text {th }}$-Anniversary Report, ed. Farah Elahi and Omar Khan, London: Runnymede Trust, 13-16. Available at: https://www.runnymedetrust.org/uploads/Islamophobia\%20Report\%202018\%20FINAL.pdf 
Crenshaw, Kimberlé. 1989. Demarginalizing the Intersection of Race and Sex: A Black Feminist Critique of Antidiscrimination Doctrine. Feminist Theory and Antiracist Politics. University of Chicago Legal Forum, 1, 8: 139-167, http://chicagounbound.uchicago.edu/uclf/vol1989/iss1/8

Dietze, Gabriele. 2016a. Ethnosexismus. Sex-Mob-Narrative um die Kölner Silvesternacht. Movements, 2, 1, https://movements-journal.org/issues/03.rassismus/10.dietze--ethnosexismus.html.

Dietze, Gabriele. 2016b. Das Ereignis Köln. Femina Politica, 1: 93-102. https://doi.org/10.3224/feminapolitica.v25i1.23412.

Drueke, Ricarda. 2016. Die TV-Berichterstattung in ARD und ZDF über die Silvesternacht 2015/16 in Köln. e-paper Heinrich-Böll-Stiftung, Gunda Werner Institut.

Esposito, John L., and Ibrahim Kalin. 2011. Islamophobia: The Challenge of Pluralism in the $21^{\text {st }}$ Century. Oxford: Oxford University Press.

Farris, Sara R. 2017. In the Name of Women's Rights. The Rise of Femonationalism. Durham: Duke University Press.

Farris, Sara R., and Catherine Rottenberg. 2017. Introduction: Righting Feminism. New Formations: A Journal of Culture, Theory, Politics, 91(3): 5-15.

Goldberg, Daniel T. 2006. Racial Europeanization. Ethnic and Racial Studies 29 (2): 331-364.

Hall, Stuart. 1995. The whites of their eyes. Racist Ideologies and the Media. In Gender, Race and Class in Media. A Text Reader, ed. Gail Dines, and Jean M. Humez, Thousand Oaks: Sage, 18-22.

Hall, Stuart. 1997. The Spectacle of the 'Other'. In ed. Stuart Hall, Representation. Cultural Representations and Signifying Practices, London: Sage, 223-290.

Hall, Stuart, Brian Roberts, John Clarke, Tony Jefferson, and Chas Critcher. 1978. Policing the Crisis. Mugging, the state and law and order. London: Macmillan.

Hark, Sabine, and Paula-Irene Villa. 2017. Unterscheiden und herrschen. Ein essay zu den ambivalenten Verflechtungen von Rassismus, Sexismus und Feminismus in der Gegenwart. Bielefeld: Transcript.

Hund, Wulf D. 2017. Wie die Deutschen weiss wurden. Kleine (Heimat)Geschichte des Rassismus. Stuttgart: J.B. Metzler.

McCombs, Maxwell. 2014. Setting the Agenda: The Mass Media and Public Opinion. Cambridge: Polity Press.

Meer, Nasar 2013. Racialization and Religion: Race, Culture and Difference in the Study of AntiSemitism and Islamophobia. Ethnic and Racial Studies 36 (3): 386-398

Meer, Nasar, and Tehseen Noorani. 2008. A Sociological Comparison of Anti-Semitism and Anti-Muslim Sentiment in Britain. The Sociological Review 56 (2): 195-219.

Nyhagen, Line, and Halsaa Beatrice. 2016. Religion, Gender and Citizenship: Women of Faith, Gender Equality and Feminism. Basingstoke: Palgrave Macmillan.

Pickering, Michael. 2001. Stereotyping. The Politics of Representation. Basingstoke: Palgrave.

Said, Edward. 2003. Orientalism. London: Penguin books.

Schneider, Felix. 2016. Die Kölner Silvesternacht. (re)Konstruktion eines diskursiven Ereignisses. DISS Journal, 31: 16-17 
Seongcheol, Kim. 2017. The populism of the Alternative for Germany (AfD): an extended Essex School perspective. Palgrave Communications, 3.

Smedley, Audrey. 1993. Race in North America: Origins and Evolution of a World View. Boulder:

Westview Press.

Solomos, John. 2014. An Appreciation. Stuart Hall: articulations of race, class and identity. Ethnic and Racial Studies 37, 10: 1667-1675.

Stöckle, Silke, and Marion Wegschneider. 2016. Sexism is not an imported product. RS21, 08.01.2016, http://rs21.org.uk?2016/01/08/sexism-is-not-an-imported-product/

Taras, Raymond. 2013. Islamophobia never stands still: race, religion, and culture. Ethnic and Racial Studies 36, 3: 417-433.

Weber, Beverley. 2016a. 'The German Refugees “Crisis” after Cologne: The Race of Refugee Rights'. Language Notes 54: 77-92.

Weber, Beatrice. 2016b. 'We must talk about Cologne'. Race, Gender, and Reconfigurations of 'Europe'. German Politics and Society 121, 34, 4: 68-86.

Wigger, Iris 2010. “'Black Shame' — The Campaign against 'Racial Degeneration' and Female Degradation in Interwar Europe.” Race \& Class 51 (3): 33-46.

Wigger, Iris 2017. “The 'Black Horror on The Rhine'. Intersections Of Race, Nation, Gender and Class in 1920s Germany." London: Palgrave Macmillan.

Word Count: 9314

\section{Figure 1}

Caption: Two newspaper images Süddeutsche Zeitung (left) and FOCUS (right) 9.1.2016

Source: http://www.migazin.de/2016/01/12/nach-koeln-kritik-titelseiten-focus/

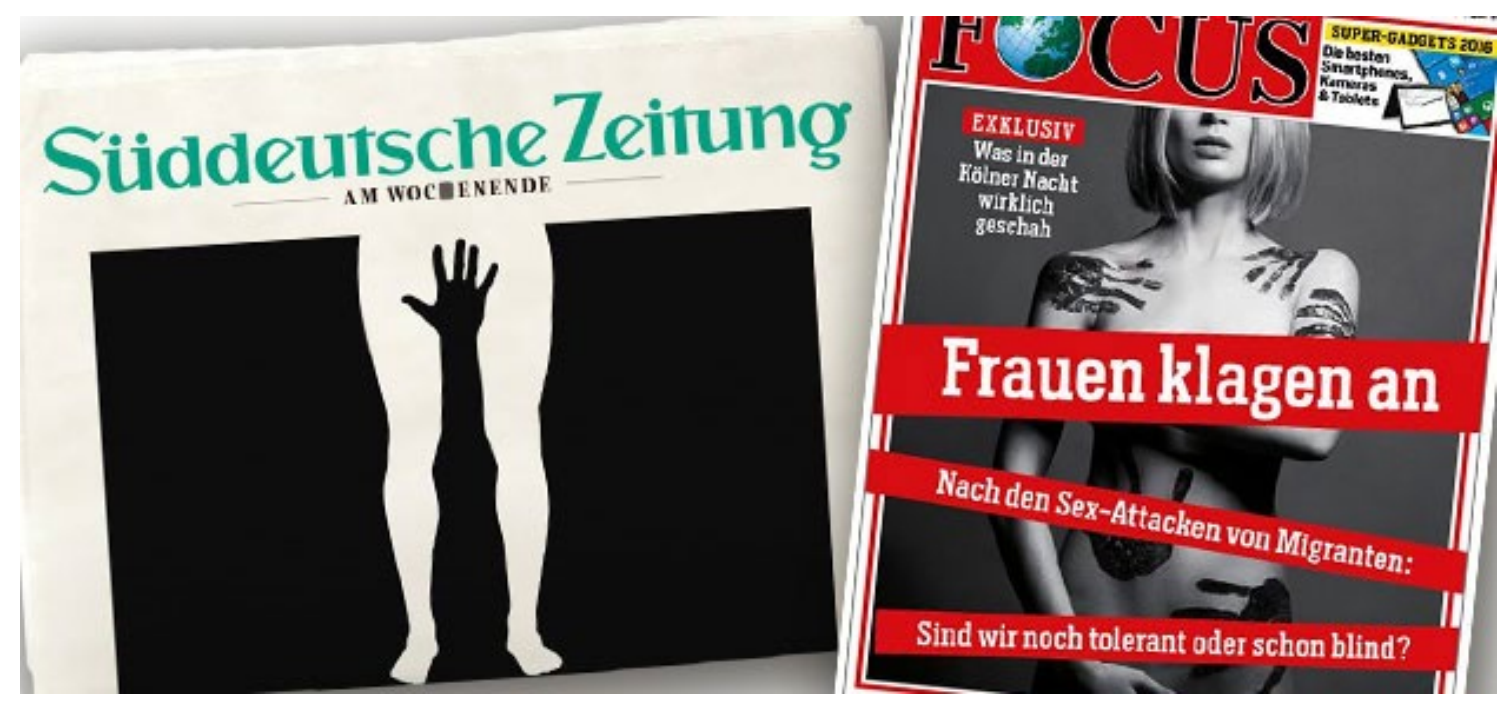


Acknowledgements

I would like to thank the British Academy and the Leverhulme Trust very much for supporting my research on this topic and for funding my research project The end of tolerance?! Race, Sex and Violence in Germany's media discourse on migration. I would also like to thank my Sociology colleagues Line Nyhagen, Dave Elder-Vass, Karen Lumsden and Thomas Thurnell-Read for reading and commenting on earlier drafts of this article. 